"Impact of internal and external factors on the net interest margin of banks in Indonesia"

Endri Endri (D https://orcid.org/0000-0002-8613-6149

AUTHORS

R https://publons.com/researcher/3527011/endri-endri/

Asti Marlina (D) https://orcid.org/0000-0002-2841-2571

Hurriyaturrohman (D) https://orcid.org/0000-0003-4706-5058

ARTICLE INFO

Endri Endri, Asti Marlina and Hurriyaturrohman (2020). Impact of internal and external factors on the net interest margin of banks in Indonesia. Banks and Bank Systems, 15(4), 99-107. doi:10.21511/bbs.15(4).2020.09

DOI http://dx.doi.org/10.21511/bbs.15(4).2020.09

RELEASED ON

Thursday, 10 December 2020

RECEIVED ON

Friday, 23 October 2020

ACCEPTED ON

Thursday, 03 December 2020

(c) EY

LICENSE

This work is licensed under a Creative Commons Attribution 4.0 International License

JOURNAL "Banks and Bank Systems"

ISSN PRINT $1816-7403$

ISSN ONLINE 1991-7074

PUBLISHER

LLC "Consulting Publishing Company "Business Perspectives"

FOUNDER

LLC “Consulting Publishing Company "Business Perspectives"

NUMBER OF REFERENCES

47
NUMBER OF FIGURES

0
NUMBER OF TABLES

1

(C) The author(s) 2021. This publication is an open access article. 


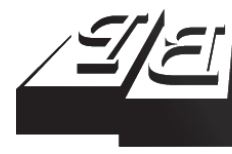

BUSINESS PERSPECTIVES

(O)

LLC "CPC "Business Perspectives"

Hryhorii Skovoroda lane, 10, Sumy, 40022, Ukraine

www.businessperspectives.org
Received on: $23^{\text {rd }}$ of October, 2020 Accepted on: $3^{\text {rd }}$ of December, 2020 Published on: $10^{\text {th }}$ of December, 2020

(c) Endri Endri, Asti Marlina, Hurriyaturrohman, 2020

Endri Endri, Ph.D., Associate Professor, Graduate Faculty, Master of Management, Universitas Mercu Buana, Jakarta, Indonesia. (Corresponding author)

Asti Marlina, Ph.D., Assistant Professor, Faculty of Economics and Business, Universitas Ibn Khaldun, Bogor, Indonesia.

Hurriyaturrohman, Ph.D., Lecturer, Faculty of Economic and Business, Universitas Ibn Khaldun, Bogor, Indonesia.

\section{IMPACT OF INTERNAL AND EXTERNAL FACTORS ON THE NET INTEREST MARGIN OF BANKS IN INDONESIA}

\begin{abstract}
This study aims to assess the impact of bank-specific factors and macroeconomic indicators on the net interest margin (NIM) of commercial banks in Indonesia. Data from Indonesian commercial banks are used. Data are collected from the banks' annual reports and the Financial Services Authority (OJK) for the period 2008 to 2018. A panel data regression model is used to estimate the effect of bank-specific and macroeconomic factors. The results prove that the variables of Non-Performing Loans (NPL), Loan to Deposit Ratio (LDR), Return on Assets (ROA), Interest Rate (SBI), and Exchange Rate (FOREX) affect NIM. The exchange rate variable has a predominant effect, while the NPL factor has a less strong influence on NIM. The empirical evidence from this research is important for commercial banks in Indonesia to improve operational efficiency through NIM performance. Internal and external factors of a bank should be subject of attention of bank managers.
\end{abstract}

\section{Keywords net interest margin, bank-specific, macroeconomics, commercial bank}

\section{JEL Classification E44, E51, G21}

\section{INTRODUCTION}

The role of a financial intermediary is an important task for banks to support their operations both individually and in companies that affect economic growth. According to Werner (2016), banks function as a liaison institution to distribute funds from economic entities with excess funds to other parties with deficit funds. As a result, banks receive deposits and loans at interest rates to depositors and borrowers. Interest is paid to depositors, and interest charged to recipients of funds results in a distribution called interest differentials to banks, where ideally the bank gives lower interest to savers and charges higher fees to creditors. According to this definition, the net interest margin (NIM) is the difference between the income and expenditure of the bank interest divided by the total value of bank assets (Tarus et al., 2012). Increased competition drives banks to improve efficiency through lower net interest margins (Angori et al., 2019). Wide net interest margins make it difficult for banks to expand their functions as financial intermediary institutions, because low deposit rates reduce the motivation to save and vice versa, with high loan rates being a heavy burden for companies in investing (Claessens et al., 2017). Information related to the bank's NIM ratio is also part of the signal in investment decision making (Endri \& Fathony, 2020). As a result, banks should be able to perform an intermediary function at the lowest possible cost to boost overall economic growth.

An interesting phenomenon in the national banking shows the fluctuating NIM ratio during the period 2008 to 2018. In 2008, the NIM 
ratio reached a value of $5.98 \%$ and increased to $6.28 \%$ in 2009 , and thereafter until 2018 , the NIM ratio has decreased. In 2017, the value of the NIM ratio was 5.26\% (an increase of 5.28\%). On average, NIM of banks experienced a decline in 2008-2018. The decline in the NIM ratio demonstrates that this condition shows higher banking operational efficiency and affects the improvement of national banks' performance. As for the NIM of national banks, which tends to be high, the Financial Services Authority $(\mathrm{OJK})$ issued a new regulation in the form of an NIM. The highest limit of the NIM ratio, according to the determined rules, is $4 \%$ with the aim of increasing the competitiveness of national banks in facing competition with other banks in ASEAN countries, where the banks' NIM ratio ranges from $2 \%$ to $4 \%$. BUKU 4 bank group is the national bank with the largest assets and has the highest NIM ratio (6.36\%) as of December 2018, which grew by 126 bps (1.26\%) from 5.10\% in December 2017. Furthermore, followed by BUKU 1 bank groups that have an NIM ratio of 5.28\%, there was an increase of 7 bps $(0.07 \%)$ from $5.82 \%$ and a position above the banking industry average by $5.28 \%$. As for the other two bank groups, BUKU 2 with NIM increased by 117 bps (1.17\%) from 3.54\% to $4.71 \%$ and BUKU III with NIM increased by 105 bps (1.05\%) from $3.44 \%$ to $4.49 \%$ in the same time period. The NIM ratio of the two banks in the BUKU group is below the banking industry's average of $5.39 \%$. This study aims to analyze the internal and external factors that determine the NIM ratio of Indonesian conventional banks by grouping two factors, namely bank specific factors and macroeconomic variables, and using a panel data regression model.

\section{LITERATURE REVIEW}

Net interest margin (NIM) is broadly defined as the difference in interest charged to loan recipients and interest income obtained by savers as part of the bank's total productive assets (Ho \& Saunders, 1981; Maudos \& de Guevara, 2004). It should be borne in mind that in a limited sense, interest income and expenses are included as a ratio of interest income assets. This definition of the NIM ratio has two drawbacks:

1) it does not consider bank income from fees and commissions; and

2) it deviates from the marginal distribution (Brock \& Suarez, 2000).

Usually, NIM is a measure of the actual difference in bank interest or past differences (expost spread). According to Demirguc-Kunt and Huizinga (1999), this difference is preferred, since it is usually available periodically at comparable levels of consolidation.

Previous research on the influence of internal factors and macroeconomic indicators on the bank's NIM ratio provides contradictory findings. Certain bank characteristic factors have been shown to influence NIMs, such as operational expenses, loans, capital adequacy, liquidity, credit quality, bad credit, interest rate risk, opportunity costs for bank reserves, size of bank assets and ownership structure. For macroeconomic indicators, inflation rate and economic growth indicate the most influential NIM determinant. However, it is understood that the consensus is that high inflation contributes to an increase in NIM, and the impact of real GDP growth remains ambiguous (Carbó \& Rodríguez, 2007). Conversely, real GDP growth has a negative impact on bank NIMs based on the fact that (i) creditworthiness of borrowers and net worth decrease during recessions and increase in lending rates (Berger et al., 2020), and (ii) economic growth increases, lowering bank standards (Carbó \& Rodríguez, 2007). On the other hand, there is a positive effect of economic growth on NIM due to the fact that loan demand increases during the increase cycle.

Demirgüç-Kunt and Huizinga (1999) examine the factors that influence NIM ratios and profitability using a sample of banks in 80 countries for 19881995. The results showed the following determinants of NIM and bank profitability: bank specific factors, macroeconomic variables, bank taxation, regulations and institutions, and financial structure. These findings also reveal that a small market concentration causes low margins and profits. Previous studies conducted by Ho and Saunder (1981) have been developed by Angbazo (1997) and Saunder and Schumacher (2000) who continue the NIM ra- 
tio function model framework. Previous studies of the determinants of NIM ratios have been extensively developed, for example by Fungacova and Ponghyosan (2011) in Russia. This study, in addition to the factors that have been developed by the Ho and Saunders model, proves the influence of the bank ownership structure on the NIM ratio. Doliente (2005) confirms the factors influencing the NIM performance as intermediary institutions (dealer models). However, non-micro factors are also taken into consideration. Based on an intergovernmental research approach, Claeys and Vennet (2008) prove that there are relatively significant differences in banking behavior in more developed and developing countries. Based on this analysis, it can be concluded that banks in a developing country have relatively higher NIM ratios compared to those in developed countries. Similar information was obtained from Berger et al. (2020) who concluded that the financial sector, with its liberalization program, had strengthened the competitive conditions and efficiency of the banking sector in order to be able to suppress the level of banking net interest margin ratio in Colombia.

In addition, macroeconomic variables are an important factor in determining bank NIM performance, because macroeconomic factors are considered as external factors affecting operational processes in the banking industry; better economic conditions can increase credit demand, which drives an increase in loan interest expense when borrowers do not replace loans (Kashyap \& Stein, 2000). A bank's decision to raise or lower lending and savings rates as a reaction to external shocks in the money market is the same as the company's decision regarding commodity prices as a reaction to changes in costs. Some studies prove that macroeconomic factors do not affect NIM (Gounder \& Sharma, 2012; Husni et al., 2008), while other studies prove otherwise (Alper \& Anbar, 2011; Tarus et al., 2012). Hamadi and Awdeh (2012) estimate and analyze the factors influencing the NIM ratio in the banking system of Lebanon by making a difference between foreign and local banks. Important findings from this research are differences in bank size, liquidity, capital, and credit risk in the NIM ratio. For local banks, the effect is negative, but not significant for foreign banks. In contrast, macroeconomic variable conditions and the structure of the banking industry have a weaker effect on the NIM ratio of foreign banks compared to the NIM ratio of local banks. GDP growth has a negative impact on the NIM ratio, while inflation and interest rate policies have a positive impact. However, in the same country (Lebanon), Saad and El-Moussawi (2012) found the opposite. GDP growth has a positive effect on the NIM ratio, while inflation does not affect it.

\section{RESEARCH METHODOLOGY}

In accordance with the objectives, the study estimates and analyzes the factors affecting the NIM ratios of banks listed on the Indonesia Stock Exchange (IDX) in 2008-2018. Determinants of bank NIM performance ratio consist of internal factors in the form of the bank performance ratio, namely CAR, NPL, LDR, BOPO, and ROA ratios, as well as bank external factors in the form of macroeconomic variables consisting of Reference Bank Indonesia's interest rates (SBI), inflation, and exchange rates. The population used as the object of this study includes conventional bank listed on the IDX from 2008 to 2018. The research sample was selected based on the following criteria:

1) banks listed on the IDX from 2008 to 2018;

2) banks were commercial banking companies operating conventionally; and

3) banks had complete data availability during the study period, both for internal and external factors.

Based on the sample selection criteria, eleven sample banks participate in this study, which will then be estimated using the panel data regression model represented by the following formula:

$$
\begin{aligned}
& N I M_{i t}=\alpha_{0}+\alpha_{1} C A R_{i t}+\alpha_{2} N P L_{i t}+ \\
& +\alpha_{3} L D R_{i t}+\alpha_{4} B O P O_{i t}+\alpha_{5} R O A_{i t}+ \\
& +\alpha_{6} S B I_{i t}+\alpha_{7} I N F_{i t}+\alpha_{7} \beta_{7} F_{O R E X}+\varepsilon_{i t},
\end{aligned}
$$

where NIM - Net Interest Margin; CAR - Capital Adequacy Ratio; NPL - Non Performing Loan; $L D R$ - Loan to Deposit Ratio; BOPO - Operational Costs Operating Income; $R O A$ - Return on Assets; SBI - BI-rate; FOREX - Exchange Rates; and $I N F$ - inflation. 


\section{RESULT}

The estimation results of the determinants of banking NIM ratios by applying the fixed effects panel data regression model are summarized in Table 1, and for the estimation results, models can be written in the panel data regression equation as follows:

$$
\begin{aligned}
& \mathrm{NIMi}_{t}=11.1287+0.03203 \cdot \mathrm{CAR}_{i t}- \\
& -0.0630 \cdot N P L_{i t}+1.3986 \cdot \mathrm{LDR}_{i t}+ \\
& +0.0008 \mathrm{BOPO}_{i t}+0.6094 \cdot \mathrm{ROA}_{i t}+ \\
& +0.1498 \cdot \mathrm{SBI}_{i t}+0.0325 \cdot \mathrm{INFi}_{t}- \\
& -1.6028 \cdot \mathrm{FOREX}_{i t}+[C X=F]
\end{aligned}
$$

where $\mathrm{C} i$ - constant panel fixed effect data regression for the $i$-th bank, $i=1, \ldots 1$.

From the equation model above, the hypothesis for each regression coefficient of the fixed effect panel data regression model is tested on the dependent variable performance ratio of the bank NIM using the t-test. T-test was conducted to empirically prove that each independent variable used in this study could partially determine the ratio of banking NIM performance as a variable that was explained (dependent variable) significantly with a confidence level of 95 percent or alpha equal to five percent $(\alpha=0.05)$. T-test shows that NPL and exchange rates negatively and significantly affect the bank's NIM ratio, while the variables of LDR, $\mathrm{ROA}$, and Bank Indonesia interest rates (SBI) positively and significantly affect the banking NIM ratio. CAR, BOPO, and inflation have no effect on the performance of the banking NIM. Based on the estimation results of the panel data regression method using the fixed effects model, of the eight independent variables, which are bank financial performance factors, and macroeconomic factors that affect the banking NIM ratio, there are five variables that have a significant effect, namely NPL, LDR, ROA, SBI variables, and FOREX. Out of the variables that have a significant impact, macroeconomic variables, such as FOREX, are the most dominant variables affecting the banking NIM with a coefficient of 1.60 with a negative direction sign. The NPL ratio is the smallest in-

\begin{tabular}{|c|c|c|c|c|}
\hline Variable & Coefficient & Std. err. & t-stat & Prob. \\
\hline $\bar{C}$ & 11.12867 & 5.491970 & 2.026350 & 0.0309 \\
\hline CAR & 0.033028 & 0.017804 & 1.865509 & 0.1455 \\
\hline$N P L$ & -0.063048 & 0.018979 & -3.316971 & 0.0004 \\
\hline$L D R$ & 1.398629 & 0.565422 & 2.473602 & 0.0164 \\
\hline$B O P O$ & 0.000873 & 0.002969 & 0.294038 & 0.7453 \\
\hline$R O A$ & 0.609373 & 0.237636 & 2.563547 & 0.0139 \\
\hline$S B I$ & 0.149845 & 0.073924 & 2.027014 & 0.0398 \\
\hline INF & 0.032487 & 0.035787 & 0.907786 & 0.7129 \\
\hline FOREX & -1.602816 & 0.781743 & -2.050310 & 0.0309 \\
\hline$R^{2}$ & 0.810238 & \multicolumn{2}{|c|}{ Mean dep. var. } & 19.93715 \\
\hline Adjusted $R^{2}$ & 0.798376 & \multicolumn{2}{|c|}{ S.D. dep. var. } & 10.61429 \\
\hline $\begin{array}{l}\text { S.E. of } \\
\text { regression }\end{array}$ & 3.410372 & \multicolumn{2}{|c|}{ Sum² resid. } & 1171.836 \\
\hline F-stat. & 21.32162 & \multicolumn{2}{|c|}{ D-W stat. } & 1.183614 \\
\hline Prob. (F-stat.) & \multicolumn{4}{|c|}{0.000001} \\
\hline
\end{tabular}
fluencing factor with a coefficient of 0.06 with a negative direction sign.
Table 1. Determination of NIM

Source: Processed data (2020)

Based on testing individual parameters in the fixed effects panel data regression model using the t-test, it can be proven that five of the eight determinant variables estimated in this study, both from the bank's internal factor group and the bank's external factors, affect the bank's NIM ratio. Next, to test hypotheses together, fixed effect model equations for all determinant variables are included in the panel data regression model using the F-test. The results of the F-test (see Table 1) show that the F-Statistic value is 21.32162 with a Prob value. 0.0000 smaller than alpha $=0.05$, which means that $\mathrm{H} 0$ is rejected. This shows that all determining variables estimated significantly affected the bank's NIM ratio with a 95 percent confidence level. Testing goodness-of-fit using the coefficient of determination $\left(\mathrm{R}^{2}\right)$ gives a number 0.8102 , which can be interpreted as fluctuations in changes in the bank NIM ratios that can be explained by all the determinants of bank NIM ratios estimated in this study and amounted to 81.02 percent, while other factors not included in this research model are 9.98 percent.

\section{DISCUSSION}

Bank specific factors, such as the CAR ratio, have no effect on the performance of the national banking NIM ratio. The CAR ratio is a comparison of bank performance used to calculate the bank's capital adequacy in order to support assets vulnerable to risk. In other words, the CAR ratio reflects the 
ability of banks to avoid risk on risk assets (risk aversion). This means that the higher the CAR ratio's value, the stronger the bank's capital strength in maintaining the possibility of loss risk arising from risk operation. Maudos and de Guevara (2004) and Shahnia et al. (2020) prove that the CAR ratio has a positive impact on the NIM ratio. The positive effect of the CAR variable on interest margins shows that banks reject risk and want a higher NIM ratio to protect the risk of greater costs from equity financing compared to financing sourced from outside the company. Claessens et al. (2017) prove the opposite, that banks with low capitalization are reasons for taking more risk (associated with higher margins) to generate higher returns. In addition, large capital banks invest more wisely, due to the greater funding risk (Claessens et al., 2017; Sugianto et al., 2020; Sunaryo et al., 2020).

The credit risk variable measured by the NPL ratio negatively and significantly affects the NIM ratio. These results prove that the higher the NPL ratio, the lower the banking NIM ratio. This result also shows that banks may prefer profits with lower margins, when the financial situation of individuals and businesses worsens. The results of this study are in line with Zhou and Wong (2008) and Fungacova and Poghosyan (2011) who argue that the NPL ratio has a negative effect on the NIM ratio. Depositors require higher premiums to store their savings in risk banks (i.e. banks with high NPL ratios). An increase in interest on savings, assuming other factors are constant, will contribute to a decrease in NIMs, building the opposite relationship between problem loans and NIMs. Fungacova and Poghosyan (2011) prove that credit risk (NPL) negatively affects the NIM ratio. An increase in bank credit risk is caused by an increase in savings interest rates, which causes the amount of bad loans to increase, thereby reducing bank interest receipts. Given the reduced bank income from the credit side and the increased burden of funds from savings in terms of direct costs, the bank's profit margins have experienced a reduction, which affects a decrease in efficiency. Different results are proven by Maudos and Solis (2009) who state that the NPL ratio (credit risk) has a positive influence on the NIM ratio. Positive sign obtained in the variable means the bank avoids risk (risk aversion) such as interest rate risk and credit rate risk. The bank will set a higher interest rate to get a larger margin.
The banking intermediary function using the LDR ratio has a positive effect on the NIM ratio of banks. The LDR ratio is used to determine how much a bank can rely on lending as an important source of liquidity in meeting the provisions of its short-term obligations, such as withdrawal of funds made by savers and the interest expense that must be given to its customers. The findings of this study are in line with previous research conducted by Raharjo et al. (2014) who prove the significant effect of LDR on the NIM ratio. The findings of this study prove that the greater LDR ratio of a bank causes the bank's NIM ratio to increase. LDR ratio is the ratio between all the volume of credits channeled by banks and funds received by banks from third parties. As the volume of lending activities provided by banks increases, the performance of the NIM ratio will improve due to the benefits of interest income or the benefits of lending.

The efficiency measured by the BOPO ratio variable has no effect on the bank's NIM ratio. This means that the volatility of the BOPO ratio does not affect the NIM ratio. A high BOPO ratio indicates that the operational costs incurred by the respective bank are more efficient, so that the implications for banks are less problematic. Referring to the theory, if the bank's BOPO ratio decreases, it means that the bank managed to divide costs to generate greater revenue. In other words, if the $\mathrm{BOPO}$ ratio gets lower, then the interest income from the credit distribution can cover the interest given to savers. Empirical research findings contradict the studies of Brock and Suarez (2000) and Khalil and Farooq (2019) who found that BOPO was an important factor influencing the NIM ratio. Gounder and Sharma (2012), Khediri and Khedhiri (2011) and Maudos and de Guevara (2004) prove that operating costs on operating income (average operating costs) positively and significantly affect net interest margins.

Bank profitability using ROA has a positive effect on bank NIM. The findings of this study indicate that the greater the bank's ROA ratio, the greater the bank's ability to get a high NIM ratio. Bank profitability shows the ability of banks to generate income that exceeds costs, in relation to bank capital and asset base (Lartey et al., 2013). Empirical research findings are in line with Siddiqui (2011) who concluded that ROA had a positive impact 
on the NIM ratio. Lepetit et al. (2008) also found that bank profitability affected the NIM ratio. Harahap et al. (2020), Endri et al. (2020), San and Heng (2013) and Kosmidou et al. (2006) show that ROA negatively affects NIM.

Interest rates as a macroeconomic factor with the use of Bank Indonesia certificates (SBI) as a reference have a positive and significant effect on banks' NIM ratios. The results of this study show that bank NIM ratios are higher with increasing SBI interest rates. SBI is a Bank Indonesia's instrument used as securities for the recognition of short-term debt in rupiah using a discount system. The findings of this study are in line with Azeez and Gamage (2013), Hamadi and Awdeh (2012) and Marinkovic and Radovic (2010) who show a positive effect of interest rates on the NIM ratio banking network. When SBI interest rates are high, this affects investors who are more interested in transferring funds to deposits. This was caused by an increase in SBI interest rates followed by commercial banks by raising deposit rates. The impact of funds received by banks increases because the interest offered is higher.

Empirical evidence shows that inflation as a macroeconomic variable has no effect on banks' NIM. The inflation rate itself can positively or negatively affect the bank's NIM performance. Inflation is usually a factor that has a great impact on the revenue side rather than the cost side, and can be ended with an increase in bank performance (NIM). The impact of changes in inflation itself is determined by whether inflation can be anticipated or not by banks (Pasiouras \& Kosmidou, 2007).
If the inflation rate is fully anticipated, the interest rate charged by the bank will increase to cover the inflation risk. Thus, revenues will increase faster than costs increase, so that it has a positive impact on bank performance, especially on the level of bank profitability. The results of this study differ from the findings of Tennant and Folawewo (2009), which prove that inflation has a negative effect on banks' NIM performance. Abid et al. (2014) and Hamadi and Awdeh (2012), on the contrary, prove that inflation has a positive effect on the bank's NIM ratio. Raharjo et al. (2014) show that inflation is the only external factor influencing interest margins. Saad and El-Moussawi (2012) found the opposite that inflation has no effect on NIM.

The exchange rate (FOREX) as the last macroeconomic variable in this study negatively and significantly affects the bank's NIN ratio performance. The appreciation of the rupiah against the US dollar has an impact on the lower NIM ratio. This means that when the exchange rate appreciates, it increases the loss, and in this condition the NIM ratio decreases. The results of the study reveal that if the local currency depreciates, the quality of loans may deteriorate and the bank's margins will decline. Empirical evidence from this study is in line with Ugur and Erkus (2010) and De Bock and Demyanets (2012) who state that exchange rate devaluation has an opposite effect on the NIM ratio. Different findings are presented in the study by Festic and Beco (2008), which shows that the nominal exchange rate has a positive effect on the NIM ratio. Babalola (2012) concludes that foreign exchange rates significantly influence the NIM ratio.

\section{CONCLUSION}

This study estimates and analyzes the determinants of NIM of banks listed on the Indonesia Stock Exchange in 2008-2018 using the fixed effects panel data regression method. This is because the research data used is a combination of time series data, which has an eleven-year period (2008-2018), and cross-sectional data, in which 11 banks were selected as research samples. The research findings prove that the ratio of bad loans (NPL) and the exchange rate negatively and significantly affect the performance of the bank's NIM ratio, while the LDR variable, return on assets (ROA), and SBI interest rates have a positive effect on the bank's NIM ratio. CAR, BOPO, and inflation ratios have no effect on the banking NIM performance. With regard to the joint influence, it is said that all determinants observed in the study affect the performance of the banks' NIM. Of the factors that have a significant effect, the exchange rate, macroeconomic variables are the dominant factors affecting the NIM ratio of banks, while the NPL ratio has the lowest effect. 
This research can also be expanded by adding internal factors to the bank's performance and other external factors, so that one can obtain comprehensive information regarding the determinants of bank NIM ratios. Bank internal factors can be expanded by adding several other variables, including corporate governance, operational and cost efficiency, capital structure, and progress in the development of banking information systems and technology. External factors can be developed by grouping two factors, namely specific factors in the banking industry, for example, market share, market structure, and various regulations from banking regulators (BI, OJK and LPS). As for external macroeconomic factors, research can expanded y adding several variables, including economic growth, fiscal policy, money supply, balance of payments and foreign debt, as well as regional and global factors.

\section{AUTHOR CONTRIBUTIONS}

Conceptualization: Endri Endri.

Data curation: Hurriyaturrohman.

Formal analysis: Endri Endri, Asti Marlina.

Investigation: Endri Endri.

Methodology: Endri Endri.

Project administration: Asti Marlina.

Resources: Hurriyaturrohman.

Software: Hurriyaturrohman.

Supervision: Hurriyaturrohman. V

alidation: Endri Endri.

Visualization: Asti Marlina.

Writing - original draft: Asti Marlina.

Writing - reviewing \& editing: Endri Endri.

\section{REFERENCES}

1. Abid, L., Ouertani, M. N., \& Ghorbel, S. Z. (2014). Macroeconomic and bank specific determinants of households non-performing loans in Tunisia: A dynamic panel data. Procedia Economics and Finance, 13, 58-68. https://doi.org/10.1016/S22125671(14)00430-4

2. Alper, D., \& Anbar, A. (2011). Bank specific and macroeconomic determinants of commercial bank profitability: empirical evidence from Turkey. Business and Economics Research Journal, 2(2), 139-152. Retrieved from https:// papers.ssrn.com/sol3/papers. cfm?abstract_id $=1831345$

3. Angbazo, L. (1997). Commercial bank net interest margins, default risk, interest-rate risk and offBalance sheet banking. Journal of Banking and Finance, 21(1), 55-87. https://doi.org/10.1016/S03784266(96)00025-8

4. Angori, G., Aristei, D., \& Gallo, M. (2019). Determinants of banks' net interest margin: evidence from the Euro area during the crisis and post-crisis period. Sustainability, 11(4), 1-20. https:// doi.org/10.3390/su11143785

5. Azeez, A. A. (2013). The determinants of net interest margins of commercial banks in Sri Lanka. University Journal of Commerce, 18(1), 1-16. Retrieved from https://www.semanticscholar. org/paper/THE-DETERMINANTS-OF-NET-INTERESTMARGINS-OF-BANKS-Azeez-Ga mage/5fdbcaa16a34cb9a66fa278a7 46aa36397b50bf3

6. Babalola, Y. A. (2012). The determinants of bank's profitability in Nigeria. Journal of Money, Investment and Banking, 24, 6-16. Retrieved from https:// www.academia.edu/3687782/The Determinants_of_Bank_s_Profitability_in_Nigeria

7. Berger, A. N., Molyneux, P., \& Wilson, J. O. S. (2020). Banks and the real economy: an assessment of the research. Journal of Corporate Finance, 62, 1-14. https://doi.org/10.1016/j.jcorpfin.2019.101513

8. Brock, P, L., \& Suarez, L, R. (2000). Understanding the behavior of bank spreads in Latin America. Journal of Development Economics, 63(1), 113-134. https://doi.org/10.1016/S03043878(00)00102-4

9. Carbó, S., \& Rodríguez, F. (2007). The determinants of bank margins in European banking. Journal of Banking and Finance, 31(7), $2043-$ 2063. https://doi.org/10.1016/j. jbankfin.2006.06.017

10. Claessens, S., Coleman, N., \& Donnelly, M. (2017). "LowFor-Long" interest rates and banks' interest margins and profitability: cross-country evidence (International Finance Discussion Papers No. 1197). https://doi. org/10.17016/IFDP.2017.1197 
11. Claeys, S., \& Vennet, V. R. (2008). Determinants of bank interest margins in Central and Eastern Europe: a comparison with the West. Economic Systems, 32(2), 197-216. https://doi.org/10.1016/j. ecosys.2007.04.001

12. De Bock, R., \& Demyanets, A. (2012). Bank assets quality in emerging markets: determinants and spillovers (IMF Working Paper No. WP/12/71). Retrieved from https://www.imf.org/external/ pubs/ft/wp/2012/wp1271.pdf

13. Demirgüç, A., \& Huizinga, H. (1999). Determinants of commercial bank interest margins and profitability: some international evidence. The World Bank Economic Review, 13(2), 379-408. https://doi.org/10.1093/ wber/13.2.379

14. Doliente, J. S. (2005).

Determinants of bank net interest margins of Southeast Asia. Applied Financial Economics Letters, 1(1), 53-57. https://doi.org /10.1080/1744654042000303629

15. Endri, E., \& Fathony, M. (2020). Determinants of firm's value: evidence from financial industry. Management Science Letters, 10(1) 111-120. https://doi.org/10.5267/j. msl.2019.8.011

16. Endri, E., Sumarno, A., \& Saragi, H. (2020). Analysis of financial performance: evidence from food and beverage companies in Indonesia. International Journal of Advanced Science and Technology, 29(5), 4199-4208. Retrieved from http://sersc.org/journals/index. php/IJAST/article/view/13690

17. Endri. (2019). Determinant of Firm's Value: Evidence of Manufacturing Sectors Listed In Indonesia Shariah Stock Index. International. Journal of Recent Technology and Engineering, 8(3), 3995-3999. https://doi. org/10.35940/ijrte.C5258.098319

18. Festic, M., \& Beko, J. (2008). The Banking sector and macroeconomic performance in Central European economies. Czech Journal of Economics and Finance, 58(3-4), 131-151. Retrieved from https://journal.fsv.cuni.cz/storage/1126 str_131_151--festic-beko.pdf
19. Fungacova, Z., \& Poghosyan, T. (2011). Determinants of bank interest margins in Russia: Does bank ownership matter? Economic Systems, 35(4), 481-495. https://doi.org/10.1016/j.ecosys.2010.11.007

20. Gounder, N., \& Sharma, P. (2012). Determinants of bank net interest margins in Fiji, a small island developing state. Applied Financial Economics, 22(19), 1647-1654. https://doi.org/10.108 0/09603107.2012.674202

21. Hamadi, H., \& Awdeh, A. (2012). The determinants of bank net interest margin: evidence from the Lebanese banking sector. Journal of Money, Investment and Banking, 23(23), 85-98. Retrieved from https://www.researchgate.net/ publication/325997470_The_Determinants_of_Bank_Net_Interest_Margin_Evidence_from_the Lebanese_Banking_Sector

22. Harahap, I. M., Septiania, I., \& Endri, E. (2020). Effect of financial performance on firms value of cable companies in Indonesia. Accounting, 6(6), 11031110. https://doi.org/10.5267/j. ac.2020.7.008

23. Ho, T., \& Saunders A. (1981). The determinants of banks interest margins: theory and empirical Evidence. Journal of Financial and Quantitative Analysis, 16(4), 581-600. Retrieved from https:// econpapers.repec.org/article/ cupifinqa/v_3a16_3ay_3a1981_3ai 3a04_3ap_3a581-600_5f00.htm

24. Husni, K., Al-Abadi, M., \& Hejazi, M. (2008). Determinants of commercial bank interest rate margins: evidence from Jordan. Jordan Journal of Business Administration, 4(4), 485-502. Retrieved from https://ijbssnet. com/journals/Vol_8_No_8_August_2017/4.pdf

25. Kashyap, A. K., \& Stein, J. C. (2000). What do a million observations on banks say about the transmission of monetary policy? American Economic Review, 90(3), 407-428. https://doi. org/10.1257/aer.90.3.407

26. Khalil, A., \& Farooq, U. (2019). Determinants of net interest margins in emerging markets a generalized method of moments. Journal of Quantitative Methods, 3(1), 38-55. https://doi. org/10.29145/2019/jqm/030103

27. Khediri, K. B., \& Khedhiri, H. B. (2011). Determinants of bank net interest margin in Tunisia: a panel data model. Applied Economics Letters, 18(13), 1267-1271. https:// doi.org/10.1080/13504851.2010. 534052

28. Kosmidou, K., Pasiouras, F., Doumpos, M., \& Zopounidis, C. (2006). Assessing performance factors in the UK banking sector: a multicriteria methodology. Central European Journal of Operations Research, 14(1), 25-44. https://doi.org/10.1007/s10100006-0158-5

29. Lartey, V. C., Antwil, S., \& Boadim, E. K. (2013). The Relationship between liquidity and profitability of listed banks in Ghana. International Journal of Business and Social Science, 4(3), 48-56. Retrieved from http://ijbssnet.com/journals/Vol_4_No_3_ March_2013/5.pdf

30. Lepetit, L., Nys, E., Rous, P., \& Tarazi, A. (2008). The expansion of services in European banking: Implications for loan pricing and interest margins. Journal of Banking \& Finance, 32(11), 23252335. https://doi.org/10.1016/j. jbankfin.2007.09.025

31. Marinkovic, S., \& Radovic, O. (2010). On the determinants of interest margin in transition banking: The case of Serbia. Managerial Finance, 36(12), 1028-1042. https://doi. org/10.1108/03074351011088432

32. Maudos, J., \& de Guevara, F. (2004). Factors explaining the interest margin in the banking sectors of the European Union. Journal of Banking and Finance, 28(9), 2259-2281. https://doi.org/10.1016/j.jbankfin.2003.09.004

33. Maudos, J., \& Solís, L. (2009). The determinants of net interest income in the Mexican banking system: An integrated model. Journal of Banking and 
Finance, 33(10), 1920-1931. https://doi.org/10.1016/j.jbankfin.2009.04.012

34. Pasiouras, F., \& Kosmidou, K. (2007). Factors influencing the profitability of domestic and foreign commercial banks in the European union. Research in International Business and Finance 21(2), 222-237. https://doi. org/10.1016/j.ribaf.2006.03.007

35. Raharjo, P. G., Dedi, B. H., Adler., H. M., \& Tubagus, N. A. M. (2014). Determinants of commercial bank's Interest margin in Indonesia: an analysis of fixed effect panel regression. International Journal of Economics and Financial Issues, 4(2), 295308. Retrieved from https://www. econjournals.com/index.php/ijefi/ article/view/689/pdf

36. Saad, W., \& El-Moussawi, C. (2012). The determinants of net interest margins of commercial banks in Lebanon. Journal of Money, Investment, and Banking, 23, 118-132.

37. San, O. T., \& Heng, T. B. (2013). Factors affecting the profitability of Malaysian commercial banks. African Journal of Business Management, 7(8), 649-660. Retrieved from https:// academicjournals.org/article/article1380811107_Ong\%20and\%20 Teh.pdf
38. Saunders, A., \& Schumaker, L. (2000). The determinants of bank interest rate margins: an international study. Journal of International Money and Finance, 19(6), 813-832. https:// doi.org/10.1016/S02615606(00)00033-4

39. Shahnia, C., Purnamasari, E. P., Hakim, L., \& Endri, E. (2020). Determinant of profitability: Evidence from trading, service and investment companies in Indonesia. Accounting, 6(5), 787794. https://doi.org/10.5267/j. ac.2020.6.004

40. Siddiqui, M. A. (2011). Towards determination of interest spread of commercial banks: Empirical evidences from Pakistan. African Journal of Business Management, 6(5), 1851-1862. Retrieved from https://academicjournals.org/ article/article1380718352_Suddiqui.pdf

41. Sugianto, S., Oemar, F., Hakim, L., \& Endri, E (2020). Determinants of firm value in the banking sector: random effects model. International Journal of Innovation, Creativity and Change, 12(8), 208-218.

42. Sunaryo, S., Santoni, A., Endri, E., \& Harahap, M. N. (2020). Determinants of capital adequacy ratio for pension funds: a case study in Indonesia. International
Journal of Financial Research, 11(4), 203-213. https://doi. org/10.5430/ijfr.v11n4p203

43. Tarus, D. K., Chekol, Y. B., \& Mutwol, M. (2012). Determinants of net interest margins of commercial banks in Kenya: A panel study. Procedia Economics and Finance, 2, 199-208. https:// doi.org/10.1016/S22125671(12)00080-9

44. Tennant, D., \& Folawewo, A. (2009). Macroeconomic and market determinants of banking sector interest rate spreads: empirical evidence from low and Middle Income Countries. Applied Financial Economics, 19(6), 489-507. https://doi. org/10.1080/09603100701857930

45. Ugur, A., \& Erkus, H. (2010). Determinants of the net interest margins of banks in Turkey. Journal of Economic and Social Research, 12(2), 101-118

46. Werner, R. A. (2016). A lost century in economics: Three theories of banking and the conclusive evidence. International Review of Financial Analysis, 46, 361-379. https://doi.org/10.1016/j. irfa.2015.08.014

47. Zhou, K., \& Wong, M. C. S. (2008). The determinants of net interest margins of commercial banks in mainland China. Emerging Markets Finance Trade, 44(5), 41-53. https://doi.org/10.2753/ REE1540-496X440503 